\title{
MODEL PENYELENGGARAAN PENDIDIKAN SEKOLAH ISLAM TERPADU (STUDI KASUS DI SDIT AL-BIRUNI MAKASSAR)
}

\author{
FARIDA HANU N*)
}

\begin{abstract}
Abstrak
Penelitian ini bertujuan untuk mengetahui model penyelenggaraan pendidikan alternatif di SDIT Al-Biruni Makassar Sulawesi Selatan dengan menggunakan metode kualitatif. Hasil penelitian menunjukkan: (a) Model Sekolah Islam Terpadu melalui proses pendidikan yang mengintegrasikan pelajaran umum dan agama mampu menghasilkan siswa yang memiliki sederet keunggulan kompetitif dan menguasai kemampuan akademik, non akademik, keagamaan dan sosial, (b) akses mengikuti pendidikan agama alternatif baru dirasakan pada kalangan elit muslim, karena biaya sekolah yang mahal, (c) Kementerian Agama perlu memberikan masukan yang konstruktif terkait format sekolah agama alternatif yang telah berkembang di masyarakat.
\end{abstract}

\section{Kata KunCi:}

Model, Penyelenggaraan, Pendidikan, Alternatif

\section{Abstract}

This study aims at determining an alternative model of education in SDIT Al-Biruni Makassar in South Sulawesi by utilizing qualitative methods. The results of this study indicated that: (a) Integrated Islamic school model that incorporates general and religious subjects is able to generate students with competitive excellences in academics, non-academics, religion and social relation; $(b)$ the access to this alternative model of education is currently limited to wealthy Muslims, due to the expensive school fees, (c) the Ministry of Religious Affairs should provide constructive supports to the alternative model of Islamic schools developing in the community.

\section{KeY WORDS:}

Model, Implementation, Education, Alternative

\section{A. Pendahuluan}

Pendidikan menjadi bagian penting ketika dipahami secara luas sebagai sebuah proses belajar yang berlangsung terus menerus sepanjang hayat. Pendidikan membantu manusia untuk menemukan potensi dan bakatnya serta berkembang sesuai dengan keunikan dan

*) Puslitbang Pendidikan Agama dan Keagamaan Badan Litbang dan Diklat Kementerian Agama Jl. MH. Thamrin N0. 6 Jakarta. E-Mail: farida ridwan@yahoo.com

** Naskah diterima Juli 2015, direvisi September 2015 disetujui untuk dimuat November 2015. keahliannya masing-masing, sehingga dapat dikatakan bahwa pendidikan adalah hak untuk semua orang

Namun, esensi dari pendidikan sebagai proses belajar mengoptimalkan potensi unik pribadi akhir-akhir ini menjadi bias. Proses pendidikan formal yang berjalan di sekolah-sekolah perlu dicermati lagi. Sistem pendidikan tersebut membuat para siswa menjadi obyek pasif yang harus menguasai seluruh mata pelajaran yang diberikan, bukan menjadikan para siswa tertarik dan mencintai apa yang dipelajari. Sedangkan 
kurikulum yang padat dan harus diselesaikan dalam waktu tertentu membuat para guru mengajar dengan suasana kelas yang tegang, monolog, tidak kontekstual karena terlalu teoretis dan abstrak, serta tidak mencelupkan anak ke dalam pengalaman konkret.

Menurut Tilaar, proses pendidikan yang satu arah, monolog, dan menindas perkembangan peserta didik adalah pendidikan yang tidak mengakui partisipasi. ${ }^{1}$ Selanjutnya kondisi sistem pendidikan formal sebagaimana yang dijelaskan oleh Ivan Illich, perlu upaya pembaharuan struktur pendidikan, yaitu suatu perubahan yang masih berada dalam kemampuan saranasarana yang dimiliki masyarakat. ${ }^{2}$

Saat ini, pendidikan nasional di Indonesia, perlu melakukan perubahan dan penyesuaian sistem pendidikan nasional sehingga dapat mewujudkan proses pendidikan yang lebih mengintegrasikan pelajaran Islam ke setiap pelajaran umum. Masyarakat mulai sadar dan melihat bahwa pendidikan di Sekolah Dasar merupakan pondasi dari pendidikan selanjutnya. Pembentukan kecerdasan tidak hanya dinilai dari umum tapi juga agama, khususnya agama Islam. Masa pendidikan dasar adalah masa pendidikan moral. Hal ini yang akan menentukan bagaimana anak berkembang. Kemerosotan moral yang terjadi pun juga disebabkan salah satunya oleh penanaman nilai agama pada anak usia dini yang diabaikan

Terkait dengan penanaman nilai-nilai agama yang memang merupakan hal yang tidak boleh dilupakan dalam setiap elemen pendidikan dan sesuai dengan tujuan pendidikan nasional adalah berkembangnya potensi peserta didik agar menjadi manusia yang beriman dan bertakwa kepada Tuhan Yang Maha Esa, berakhlak mulia, sehat, berilmu, cakap, kreatif, mandiri, dan menjadi warganegara yang demokratis dan bertanggungjawab. ${ }^{3}$

Pendidikan agama seyogyanya bukan hanya pentransferan materi saja tetapi lebih jauh

${ }^{1}$ HAR Tilaar, Perubahan Sosial dan Pendidikan: Pengantar Paedagogik Transformatif Untuk Indonesia (Jakarta: Grasindo, 2002), 34.

${ }^{2}$ Ivan Illich, Bebaskan Masyarakat dari Belenggu Sekolah (Jakarta: Yayasan Obor Indonesia, 2000), 99.

${ }^{3}$ Undang-Undang Nomor 20 Tahun 2003 tentang Sistem Pendidikan Nasional Pasal 3. adalah bahwa agama dapat menyatu dalam kepribadian dan panduan dalam aktifitas hidup sehari-hari. Dengan kondisi ini, mendorong orang tua untuk memilih lembaga pendidikan ideal sebagai salah satu alternatif mengatasi keterbatasan pendidikan formal dalam memberikan pelajaran agama. Dari berbagai persoalan yang ada, lahirnya berbagai sekolah alternatif yang merupakan sesuatu yang wajar sebagai upaya dari masyarakat untuk mencari solusi alternatif terhadap berbagai masalah dalam pendidikan yang ditemukan. Saat ini fenomena kemunculan salah satu lembaga pendidikan alternatif yang berada di Indonesia yaitu Sekolah Dasar Islam Terpadu menjadi pusat perhatian masyarakat.

Lembaga pendidikan tersebut dipandang sebagai model yang lebih baik, dan mempunyai berbagai bentuk keunggulan (excellencies) terkait dengan berbagai komponen sistem pendidikannya. Misalnya kualitas guru, sistem akademik, sosio-kultural sekolah, manajemen, sarana dan fasilitas, termasuk sumber-sumber belajar lainnya, serta keunggulan menyangkut profil siswa atau lulusannya.

Berdasarkan latar belakang di atas, penelitian ini perlu dilakukan. Adapun masalah penelitian di antaranya: faktor-faktor apa yang melatarbelakangi munculnya Sekolah Dasar Islam Terpadu (SDIT)? Bagaimana strategi yang dikembangkan dalam upaya peningkatan kualitas pendidikan agama (kurikulum, pendidik, peserta didik, sarana prasarana, metode pembelajaran dan sistem evaluasi)?

Tujuan penelitian ini adalah untuk mengetahui model penyelenggaraan pendidikan alternatif di SDIT Al-Biruni. Sedangkan manfaat penelitian ini diharapkan menjadi masukan sebagai bahan pertimbangan bagi pimpinan Kementerian Agama dalam hal ini Ditjen Pendidikan Islam dalam menentukan kebijakan pembinaan Pendidikan Agama pada masa mendatang.

\section{Kajian Literatur \\ Pengertian Model Penyelenggaraan \\ Pendidikan Alternatif}

Pengertian model menurut Wikipedia bahasa Indonesia, ensiklopedia bebas, adalah rencana, representasi, atau deskripsi yang menjelaskan suatu objek, sistem, atau konsep, yang seringkali 
berupa penyederhanaan atau idealisasi. Sedangkan menurut Kamus Besar Bahasa Indonesia, model adalah pola (contoh, acuan, ragam, dsb) dari sesuatu yang akan dibuat atau dihasilkan.

Dewey mendefinisikan pendidikan sebagai suatu proses pengalaman, dan kehidupan itu adalah pertumbuhan, karena itu pendidikan berarti suatu proses penyesuaian pada tiap-tiap fase serta menambah kecakapan di dalam diri seseorang. ${ }^{4}$

Definisi penyelenggaraan pendidikan menurut Peraturan Pemerintah Nomor 66 Tahun 2010 adalah kegiatan pelaksanaan komponen sistem pendidikan pada satuan atau program pendidikan pada jalur, jenjang dan jenis pendidikan agar proses pendidikan dapat berlangsung sesuai dengan tujuan pendidikan nasional. ${ }^{5}$

Adapun yang dimaksud dengan pendidikan alternatif menurut Yusuf Hadi Miarso ${ }^{6}$ adalah istilah dari berbagai program pendidikan yang dilakukan dengan cara berbeda dari cara tradisional. Pendidikan alternatif dapat mengembangkan paradigma baru yang dianggap dapat dijadikan jalan keluar sebagai lawan dari tipologi belajar konvensional. Pendidikan alternatif membangun pembelajaran yang faktual, konseptual, dan kontekstual. Sebagaimana yang dijelaskan oleh Johar, pendidikan alternatif adalah pendidikan yang berorientasi kepada proses pendidikan yang mengembangkan kompetensi: 1) metodologi, 2) konseptualisasi, 3) pemahaman konsep, 4) aplikasi, dan 5) nilai (value). ${ }^{7}$

Pemerintah memberi peluang kepada masyarakat untuk melembagakan pendidikan alternatif dengan kriterium yang mereka ciptakan namun tetap berada dalam garis kebijakan nasional pendidikan.

\section{Penyelenggaraan Sekolah Islam Terpadu}

Pendidikan Islam sekarang ini menghadapi

\footnotetext{
${ }^{4}$ Jhon Dewey, Experience and Education (Jakarta: Teraju Mizan, 2004), 24.

${ }^{5}$ Peraturan Pemerintah Nomor 66 Tahun 2010 Tentang Perubahan Atas Peraturan Pemerintah Nomor 17 Tahun 2010 Tentang Pengelolaan dan Penyelenggaraan Pendidikan.

${ }^{6}$ Yusufhadi Miarso, Pendidikan Alternatif Sebuah Agenda Reformasi (Jakarta: Jurusan Teknologi Pendidikan UNJ, 1999), 1.

7 Johar, Kurikulum yang Mencerdaskan. Visi 2030 dan Pendidikan Alternatif (Jakarta: Penerbit Buku Kompas, 2008), 149.
}

tantangan yaitu bagaimana upaya untuk membangun paradigma baru pendidikan Islam, visi, misi, dan tujuan, yang didukung dengan sistem kurikulum atau materi pendidikan, manajemen dan organisasi, metode pembelajaran untuk dapat mempersiapkan manusia yang berkualitas, bermoral tinggi dalam menghadapi perubahan masyarakat global yang begitu cepat. Perubahan yang perlu dilakukan pendidikan Islam, yaitu: [1] Membangun sistem pendidikan Islam yang mampu mengembangkan sumber daya manusia yang berkualitas agar mampu mengantisipasi kemajuan iptek untuk menghadapi tantangan dunia global menuju masyarakat Indonesia baru yang dilandasi dengan nilai-nilai ilahiyah, kemanusiaan [insaniyah], dan masyarakat, serta budaya, [2] menata manajemen pendidikan Islam dengan berorientasi pada manajemen berbasis sekolah agar mampu menyerap aspirasi masyarakat, dapat mendayagunakan potensi masyarakat, dan daerah dalam rangka penyelenggaraan pendidikan Islam yang berkualitas, [3] meningkatkan demokratisasi penyelenggaraan pendidikan Islam secara berkelanjutan dalam upaya memenuhi kebutuhan masyarakat agar dapat menggali serta mendayagunakan potensi masyarakat. $^{8}$

Dari uraian di atas, menegaskan bahwa lembaga-lembaga pendidikan Islam harus mendisain model-model pendidikan alternatif yang sesuai dengan kebutuhan perkembangan sekarang ini. Muncul pertanyaan model-model pendidikan Islam bagaimana, yang diharapkan dapat menghadapi dan menjawab tantangan perubahan yang terjadi dalam kehidupan masyarakat baik sosial maupun kultural menuju masyarakat Indonesia baru?

Saat ini di Indonesia terdapat berbagai bentuk dan jenis pendidikan Islam, apabila dicermati model-model pendidikan Islam alternatif sekarang ini sekurang-kurangnya berbasis pada empat jenis lembaga pendidikan Islam yang dapat mengambil peran dalam memberdayakan umat, yaitu pendidikan Islam berbasis pondok pesantren, pendidikan Islam berbasis pada

${ }^{8}$ Hujair AH. Sanaky, Mengembangkan Madrasah Menjadi Pendidikan Alternatif, Jurnal Pendidikan Islam, Jurusan Tarbiyah, Fakultas Ilmu Agama Islam Universitas Islam Indonesia, Vol. VIII TH VI Januari 2003, 35-45.

${ }^{9}$ Ibid. 
masjid, pendidikan Islam berbasis pada sekolah atau madrasah, dan pendidikan Islam berbasis pada pendidikan umum yang bernafaskan Islam . Kalau melihat empat jenis lembaga pendidikan Islam sebagaimana disebutkan di atas, maka Sekolah Islam Terpadu termasuk jenis pendidikan Islam berbasis pada pendidikan umum yang bernafaskan Islam.

Adapun yang dimaksud dengan Sekolah Islam Terpadu adalah sekolah yang memadukan antara pelajaran umum berdasarkan kurikulum nasional dengan pelajaran agama. ${ }^{10}$ Akhir-akhir ini Sekolah Islam Terpadu banyak diminati oleh masyarakat. SDIT kemudian menjadi model dan percontohan Sekolah Dasar Islam Terpadu di Indonesia dan menjadi trend sekolah bagi kalangan muda muslim. Sekolah Islam terpadu ini awalnya sebagai sekolah alternatif, yang ingin melahirkan generasi yang memiliki keseimbangan iman \& taqwa dengan ilmu \& teknologi.

Ada beberapa faktor yang melatarbelakangi berdirinya SDIT, diantaranya secara historis memang bangsa Indonesia tidak akan pernah lepas dari nilai-nilai religius yang menjadi sumber dan daya kekuatan bangsa. Di sisi lain masyarakat bosan dengan Sistem Pendidikan Nasional dan model pendidikan umum yang terus memisahkan antara pendidikan agama (Islam) dengan pendidikan umum. Sementara itu Sekolah Islam Terpadu menawarkan hal yang lebih dibandingkan dengan pendidikan umum. Selain mengintegrasikan pendidikan agama dengan pendidikan umum, juga mencoba menerapkan sistem pembelajaran yang tidak melulu nilai angka yang diprioritaskan, tapi mulai mengarah kepada nilai akhlak yang dimiliki anak didik. Dengan demikian, SDIT selain mengolah anak didik menjadi sumber daya manusia yang pintar juga unggul secara perilaku

Lingkungan SDIT berupaya memberikan penekanan terhadap aspek-aspek agama yang akan diajarkan kepada anak-anaknya. Sebagaimana yang diusulkan Neil Postman,

\footnotetext{
${ }^{10}$ Zuhairansyah Arifin, Dilema Pendidikan Islam pada Sekolah Elit Muslim Antara Komersial dan Marginalitas (Riau: Fakultas Tarbiyah dan Keguruan UIN Suska, 2014), 34.

${ }^{11}$ Neil Postman, Matinya Pendidikan: Redefinisi Nilai-nilai Sekolah (Yogyakarta: Jendela, 2001), 250.

${ }^{12}$ Moleong, L.J, Metodologi Penelitian Kualitatif (Bandung: Remaja Rosdakarya, Cetakan Keenambelas, 2000), 45.
}

untuk mengawali pengenalan agama di sekolah dasar dan memberi kesempatan untuk mempelajari agama. ${ }^{11}$

Dengan demikian yang dimaksud dengan model penyelenggaraan pendidikan alternatif dalam penelitian ini adalah bentuk layanan pendidikan agama pada sekolah umum berciri khas Islam dengan sistem pendidikan Islam yang integratif dan terpadu.

\section{Metodologi}

Penelitian ini menggunakan metode kualitatif,, ${ }^{12}$ yaitu prosedur penelitian yang menghasilkan data deskripsi berupa kata-kata tertulis atau lisan dari orang- orang dan perilaku yang dapat diamati.

Lokasi penelitian dilakukan pada sekolah penyelenggara pendidikan agama alternatif SD IT Al-Biruni dengan alasan: (1) sekolah tersebut mempunyai jumlah jam pendidikan agama lebih banyak dari pada di sekolah reguler (biasa), (2) kelebihan jumlah jam pendidikan agama dilakukan di luar jam sekolah, dan (3) mempunyai keunggulan dalam proses pembelajaran pendidikan agama.

Pengumpulan data dilakukan dengan menggunakan beberapa teknik: a) studi Kepustakaan; b) pedoman wawancara; wawancara dilakukan dengan dua cara; formal dan informal, c) daftar isian, yang diisi oleh stakeholders yang berguna untuk mengetahui lebih dalam tentang penyelenggaraan pendidikan agama alternatif. Informan penelitian ini terdiri dari unsur-unsur sebagai berikut: Pimpinan yayasan, pimpinan lembaga, wakil kurikulum, pendidik, dan peserta didik.

Analisis data merupakan tindak lanjut dari semua tahap kerja di atas. Di lapangan, peneliti sebagai instrumen, dengan bantuan pedoman wawancara dan studi dokumen, peneliti merekam, mencatat, mengkaji, melakukan check dan recheck, mengklasifikasi, serta mengembangkan dan mengabstraksi data dan informasi yang diperoleh dari responden. Datadata yang dihimpun melalui wawancara mendalam, kuesioner dan studi pustaka akan diolah dan dirumuskan menjadi laporan penelitian.

\section{B. Hasil Penelitian dan Pembahasan Profil Kelembagaan SD IT Al Biruni}


Sejarah berdirinya Sekolah Dasar Islam Terpadu (SDIT) Al-Biruni dimulai sejak 14 juli 2002 dengan lokasi di Hotel Marannu Jl. Sultan Hasanuddin Makassar. Pendiri dari sekolah ini adalah Muh. Arafah Kube, S.T dengan Dr. Erna Tri Herdiani. Pada pendiriannya ini mereka didampingi dan dibantu oleh teman-teman seperjuangannya yaitu Jahrim, S.T. dan Rahmia Siradjuddin, S.T. Di awal pendiriannya SDIT AlBiruni memiliki 11 siswa namun sekarang jumlah siswa sudah lebih dari dua ratus orang.

Adapun yang melatarbelakangi pendirian sekolah ini adalah semangat membangun bangsa Indonesia agar memiliki sumber daya manusia yang handal khususnya sumber daya manusia muslim yang Islami. Harapan dengan didirikannya sekolah ini adalah tercetaknya satu generasi yang mencintai Allah dan Rasulnya sehingga terbentuk suatu generasi yang cerdas dan berakhlak mulia.

Meskipun hanya dengan sarana dan prasarana yang amat terbatas, namun dengan bermodalkan semangat yang tinggi, maka SDIT Al-Biruni mulai melaksanakan proses belajarmengajar setiap hari. Dalam prakteknya pengelola melihat adanya sistem pembelajaran yang harus diefektifkan yaitu dengan merubah jam masuk sekolah yaitu dari Senin-Jum'at mulai pukul 07.15 - 14.15 wita. Hal ini berlaku pada semester II tahun ajaran 2002 - 2003 dan berlanjut sampai dengan hari ini untuk kelas 1 dan 2 sedangkan untuk kelas $3-6$ belajar mulai $07.15-16.15$ wita.

Seiring waktu akhirnya Al-Biruni memerlukan SMPIT untuk siswa siswi yang ada di Kota Makassar. SMPIT Al-Biruni berdiri pada tahun 2004 dengan siswa angkatan pertama sebanyak 11. Lokasi kedua mulai tahun 2003 di jalan mesjid Raya No. 49 Makassar sampai tahun 2007. Pada tahun 2007 sampai sekarang berada di Jalan AP Pettarani Ruko Diamond No. 12-14 Makassar. Pendirian SDIT Al-Biruni yang disahkan tahun 2003 dengan berada di bawah Yayasan Al-Biruni Mandiri, kini telah mendapatkan nilai akreditasi A pada tahun 2007 untuk tingkat SDIT.

Sekolah Dasar Islam Terpadu (SDIT) AlBiruni Makassar adalah sekolah yang menerapkan kurikulum Kementerian Pendidikan dan Kebudayaan dengan program Full Days School, yang memadukan potensi tiga penanggung jawab pendidikan (sekolah, orang tua dan masyarakat) secara proaktif dan efektif dalam bingkai kooperatif. Selain itu, SDIT AlBiruni mengintegrasikan kekayaan nilai-nilai Islami dalam setiap sesi pembelajaran dan perkembangan anak didik yang diramu dalam muatan-muatan pendidikan indoor dan outdoor.

Adapun visi dari SDIT Al-Biruni adalah "Be a Leadership School in East Indonesia." Sedangkan misi lembaga ini meliputi: a) menciptakan manusia kreatif, mandiri, berakhlak mulia, tangguh dan berwawasan global, b) mencetak peneliti muda yang handal dalam aplikasi ilmu dan teknologi, c) menjalin ukhuwah antar orang tua, pemerintah dan masyarakat.

Sedangkan tujuan sekolah ini didirikan agar siswa-siswinya mempunyai: a) aqidah yang bersih (Salimul Aqidah), b) ibadah yang benar (Shahihul Ibadah), c) pribadi yang matang (Matinul Khuluq), d) mandiri (Qadirun Alal Kasbi), cerdas dan berpengetahuan (Mutsaqqaful Fikri), e) sehat dan kuat (Qawiyul Jismi), f) bersungguh-sungguh dan disiplin (Mujahidun Linafsihi), g) tertib dan cermat (Munazhzhom Fi Syu'unihi), h) efisien (Harisun 'Ala waqtihi), i) bermanfaat (Nafiun Lighoirihi).

\section{Pengembangan Kurikulum}

Kurikulum Sekolah Islam Terpadu Al-Biruni Makassar mengacu pada kurikulum Kementerian Pendidikan dan Kebudayaan Republik Indonesia (Kurikulum KTSP) dan diintegrasikan dengan muatan-muatan pendidikan Islam. Muatan kurikulum Sekolah Islam Terpadu Al-Biruni untuk tingkat Sekolah Dasar dan Menengah Pertama adalah : a) pendidikan agama Islam, b) pendidikan Kewarganegaraan, c) pendidikan Jasmani, d) pendidikan karakter, e) Ilmu Pengetahuan Alam, f) Ilmu Pengetahuan Sosial, g) Bahasa Arab, h) Bahasa Indonesia, i) Bahasa Inggris, j) Matematika, k) Mental Aritmatika, 1) Tahfidzh Al-Qur'an, m) Teknologi Informatik (TIK), n) Kerajinan Tangan dan kesenian dan o) Pramuka.

Berpijak pada visi misi, dan tujuan serta mendukung sasaran yang dibidik maka karakteristik sekolah Islam Al-Biruni dirancang dengan sistem terpadu dengan optimalisasi fungsi sekolah sebagai media dan sentra kegiatan siswa yang memiliki tiga kriteria dasar : 1) guru tidak hanya berperan sebagai pengajar (mudarris) tetapi juga sebagai pendidik setia yang memahami 
perkembangan siswa sekaligus eksistensinya menjadi sumber keteladanan yang nyata bagi siswa, 2) lingkungan pembelajaran dan pendidikan dirancang tidak sebatas bangunan sekolah tetapi melibatkan pihak-pihak terkait yang mendukung pengetahuan dan pengembangan pembelajaran anak didik, dan 3) proses pendidikan bernuansa religius dan terpadu sehingga terbentuk karakter keagamaan yang baik, berinteraksi secara simbiosis mutualistik (ta'aawun bil khayri), saling mengingatkan dan menasehati (tawaashau bil haq wa shabr) dan tercipta masyarakat belajar (learning society) yang mampu mengembangkan potensi dasarnya secara terus menerus dan berkesinambungan sehingga siap menjadi pelajar sekaligus pengajar.

Selanjutnya sekolah ini melakukan pengembangan aspek kurikulum pendidikan agama melalui revisi dan evaluasi dilakukan setiap satu semester sekali, pengembangan kurikulum dilakukan dalam satu tahun tetapi metode pembelajaran dalam satu semester. Sedangkan ruang lingkup materi yang diajarkan dan dikembangkan dalam pendidikan agama menyangkut aspek agama, praktek ibadah dalam keseharian pembelajaran, hafalan Al-qur'an di mata pelajaran tahfiz dan pemahaman ada di pembelajaran di kelas. Jenis materi tersebut diajarkan dan dikembangkan agar siswa memahami Islam seutuhnya dan mau melaksanakan Islam dengan senang hati melalui pola pengaturan waktu pemberian pendidikan agama yang sudah dijadwalkan sebagai berikut: alokasi tahfiz 1 jam sehari, praktek ibadah wudhu, shalat dhuha, dhuhur dan ashar dilakukan setiap hari pada jam istirahat, mentoring sebagai pendalaman materi agama Islam 1,5 jam per pekan. Materi mata pelajaran termasuk sejarah, aqidah akhlak ada dalam pelajaran selama 2 jam dalam satu pekan.

\section{Sistem Rekruitmen Pendidik}

Sekolah Dasar Islam Terpadu Al-Biruni Makassar diasuh oleh para guru yang siap menjadi pendidik dan senang mengikuti program-program pengembangan sumber daya manusia di bidang pendidikan. Mereka adalah tenaga profesional lulusan Program D3 hingga S3 dari Perguruan Tinggi Negeri dan swasta yang tengah dipersiapkan melalui ratusan jam pelatihan kependidikan yang terdiri dari Quantum Learning, Quantum Teaching, Efektif dan berbagai skill, Active Learning, Psikologi Perkembngan, Menjadi Guru Efektif dan berbagai skill profesi lainnya.

Sistem rekruitmen pimpinan dilakukan melalui beberapa tahap di antaranya: a) seleksi administrasi, wawancara pertama, psikotest, mikroteaching, dan wawancara kedua. Adapun kriteria kualifikasi kepala sekolah: a) pimpinan diupayakan sudah di Al-Biruni minimal 2 tahun, b) pendidikan minimal S1, c) punya minat dalam pendidikan, diutamakan pernah dan sedang mengikuti proses tarbiyah, d) senang dengan anak-anak, e) memiliki jiwa leadership, f) memiliki visi: niat untuk meningkatkan sekolah: siap bekerja keras dan g) memiliki integritas moral yang tinggi: siap bekerja full days.

Sedangkan sistem rekruitmen pendidik dilakukan seleksi ketat mulai dari administrasi, wawancara, psikotest dan mikroteaching. Adapun kriteria kualifikasinya sbb: a) pengalaman mengajar minimal 2 tahun, b) punya sikap dalam melakukan Islam secara utuh dalam kehidupan sehari-hari, c) siap bekerja full days. Dan sistem rekruitmen peserta didik diantaranya dengan menggunakan seleksi, untuk anak kelas 1 SD dites melalui kematangan sekolah sedangkan untuk sekolah kelas 2 dan seterusnya melalui tes kemampuan akademiknya.

\section{Pengembangan Inovasi Pembelajaran pada Aspek IQ, EQ dan SQ}

SDIT Al-Biruni memadukan keseimbangan IQ,EQ dan SQ. Hal ini ditandai dengan beberapa program dan kegiatan sekolah yang meliputi kajian hafalan Al-qur'an melalui tahfiz, kedalam al Islam dalam 6 mata pelajaran atau 3 jam per pekan, praktek ibadah setiap hari mulai awal sekolah dengan do'a belajar, wudu, shalat dhuha, dhuhur dan ashar, serta mabit yang diselanggaran satu bulan sekali, tadabur alam dalam bentuk outbond, pekan ramadhan yang berisikan bakti sosial, pasar murah untuk kaum dhuafa, zakat dll.

Metode baru yang dikembangkan dalam proses pembelajaran pendidikan agama adalah metode aktive learning dan tematik. Metode pembelajaran ini biasanya akan terus dievaluasi dalam satu semester, jika setelah dievaluasi tidak cukup bagus maka dilakukan perubahan dalam 
semester selanjutnya. Inovasi pembelajaran diterapkan dalam proses pembelajaran melalui pemberian materi disesuaikan dengan kurikulum tentang metode diserahkan pada guru dengan ketentuan aktive learning untuk siswa.

Sekolah mengembangkan dan memadukan keseimbangan Intelligence Quotient (IQ), Emotional Quotiont (EQ) dan Spiritual Quotient (SQ) dalam proses pembelajaran dalam bentuk meramu program/kegiatan sehingga terdapat keseimbangan di antara semuanya. Misalnya acara outbond atau tadabur alam. Acara terdiri dari praktek ibadah shalat malam, wudu, shalat fardhu berjamaah, pentas seni di malam hari, pada acara mencari jejak pelajaran sekolah pun keluar, anak berlatar mandiri jauh dari orang tua dan belajar bersosialisasi bersama temantemannya.

Kegiatan lain, misalnya pekan ramadhan siswa belajar tentang keislaman mulai dari puasa dll melalui ramadhan event kemudian dirangkai dengan bakti sosial di panti asuhan untuk mengasah emosionalnya, mengadakan tilawah bersama setiap pagi hari untuk meningkatkan spiritual anak dan belajar seperti biasa untuk meningkatkan kecerdasan anak. Tempat pembelajaran dapat dilakukan di kelas, laboratorium, dan di tempat panti asuhan.

Dari hasil wawancara terungkap bahwa bagi peserta didik materi pelajaran yang paling penting dipelajari adalah aqidah akhlak, karena membuat pondasi dan dasar pada anak tentang tauhid sebagai dasar pembentukan sikap dan akhlak di kemudian hari. Metode pembelajaran yang paling disukai peserta didik adalah pembelajaran game dan outbond yang dikemas dalam bentuk permainan yang sarat dengan makna dan hikmah dan dilakukan di alam terbuka.

\section{Pemanfaatan Sarana Pendidikan dan Media Pembelajaran}

SDIT dalam mengelola sistem pendidikan menggunakan sarana dan media pembelajaran yang lengkap agar hasil pendidikannya lebih optimal. Fasilitas yang digunakan meliputi: a) ruangan kelas dilengkapi dengan $\mathrm{AC}, \mathrm{b}$ ) aula serbaguna, c) akses internet wireless SDT AlBiruni menyediakan akses internet wireless di wilayah sekolah, d) laboratorium komputer, terdapat 10 set Personal Computer (PC) dan dihubungkan dengan Local Area Network yang digunakan untuk browsing materi dan perkembangan aktual bagi dunia Islam, e) laboratorium IPA, laboratorium ini menjadi sarana penunjang bagi mata pelajaran fisika, kimia dan biologi, f) perpustakaan, fasilitas ini terletak di lantai dua menempatkan koleksi buku, antara lain majalah, novel, buku pelajaran dll, g) mushalla/masjid, disamping sebagai sarana ibadah umat Islam, mushalla digunakan dalam mata pelajaran Agama Islam, dan h) kantin.

Dalam proses kegiatan belajar mengajar menggunakan media pembelajaran dengan bantuan LCD dan komputer untuk; sarana presentasi guru, pimpinan ataupun tamu dari luar untuk menyampaikan materi tentang Islam dan pada acara mabit untuk melihat secara visual aktifitas keislaman yang ingin diterapkan atau ayat-ayat kauniyah yang terekam dalam kaset harun yahya yang menceritakan tentang proses penciptaan manusia.

\section{Penerapan Manajemen yang Bermutu}

Pencapaian kualitas pendidikan pada SDIT Al-Biruni tidak terlepas dari konsistensi sekolah ini dalam menerapkan manajemen pendidikan yang berorientasi mutu. Penerapan manajemen pendidikan didasarkan pada prinsip penerapan Total Quality Management (TQM) yang menekankan pada upaya memenuhi kebutuhan kualitas pendidikan yang diinginkan yaitu evaluasi dan perbaikan yang terus menerus terhadap program atau kegiatan yang dijalankan.

Ranah peningkatan mutu pendidikan yang dilakukan melalui TQM tidak hanya pada proses pembelajaran active learning yang selalu dievaluasi tiap semester, tapi juga mencakup keseluruhan hal yang terkait langsung dengan komponenkomponen penting yaitu: struktur dan isi kurikulum, kebijakan kelembagaan, kualifikasi guru dan karyawan, iklim dan kultur akademik, standarisasi proses dan mutu.

\section{Iklim Sekolah yang Kondusif}

Keadaan pendidikan konvensional yang terdapat di sekolah umum, memiliki keterbatasanketerbatasan diantaranya waktu belajar yang sebentar misalnya dari 07.00-10.30. Hal ini menyebabkan orang tua harus mengisi kembali waktu anak-anak tersebut dengan les. Bagi orang tua yang sibuk kerja di luar rumah, dengan kondisi anak berada di luar kontrol lebih banyak, 
terlebih dengan banyaknya korban pelecehan seksual, perkelahian dan narkoba di sekolahsekolah, hal ini akan menjadi masalah buat keluarga. Dengan kondisi ini, orang tua cenderung merasa aman jika menitipkan anaknya di SDIT Al-Biruni yang menerapkan sistem full days school dari jam 07.00-14.15 dengan lingkungan sekolah yang kondusif, aman, dan Islami.

\section{Membangun Jaringan Kelembagaan}

Pendidikan merupakan tugas dan tanggung jawab orang tua, sekolah dan masyarakat. Orang tua sebagai pengguna hasil pendidikan memiliki tugas yang sama dalam mendidik anak. Hubungan para orangtua murid dengan pihak sekolah bersifat mutualistik dan bersama-sama mewujudkan kerjasama yang produktif dan saling pengertian. Melalui Komite Sekolah, orang tua murid dapat memainkan peran dalam membantu melancarkan proses pendidikan, memberikan masukan, saran, tanggapan, gagasan dan melakukan evaluasi terhadap jalannya proses pendidikan. Komite sekolah merupakan bagian integral dari struktur lembaga pendidikan. Dalam membangun jaringan keluar, SDIT Al-Biruni terhimpun dalam Jaringan Sekolah Islam Terpadu (JSIT) di Indonesia.

\section{Analisis dan Temuan Latar Belakang Munculnya Pendidikan Agama Alternatif}

Secara kelembagaan, terdapat beberapa faktor yang melatarbelakangi pendirian Sekolah Dasar Islam Terpadu (SDIT) Al-Biruni diantaranya adalah pertama, seiring dengan meningkatnya perekonomian masyarakat Sulawesi Selatan, para orang tua sudah mulai menyadari untuk menyekolahkan anaknya di sekolah Islam berkualitas. SDIT Al-Biruni mencoba memberikan alternatif sekolah Islam untuk orang tua agar mereka merasa aman dalam menitipkan anak-anaknya di sekolah karena terjamin pengetahuan dan keamanannya. Di lain pihak banyaknya anggapan bahwa sekolah Islam kurang bermutu di Makassar, sehingga bagi orang tua yang memiliki ekonomi menengah ke atas (segmen masyarakat elit menengah ke atas) cenderung menyekolahkan anak-anaknya ke sekolah-sekolah swasta lain yang notabene berlatar belakang agama Kristen, contoh SD
Katolik Rajawali, SD Kristen Gamaliel, SD Kristen Frater atau SD umum yang berafiliasi dengan Kristen, contoh SD Nusantara, SD Mulia Bakti. Alasan mereka memilih sekolah tersebut adalah karena kualitas akademik yang cukup bagus.

Kedua, kebutuhan terhadap kondisi lingkungan belajar yang kondusif, nyaman, aman dan Islami bagi siswa. Dengan banyaknya korban pelecehan seksual, perkelahian dan narkoba di sekolah, orang tua cenderung mencari tempat sekolah yang kondusif, aman dan Islami. Sehingga mereka aman menitipkan anaknya di sekolah. Jadi SDIT Al-Biruni mencoba menawarkan hal tersebut. Ketiga, kondisi pendidikan konvensional yang tidak memenuhi harapan dan memiliki keterbatasan. Sekolah umum belum memenuhi keinginan orang tua baik dari segi sarana ataupun secara metode pembelajarannya. Dan Keempat, corak pemikiran masyarakat semakin religius. Masyarakat sudah mulai memahami pentingnya arti pendidikan Islam bagi anak-anaknya. Masyarakat sekarang cenderung menyekolahkan anaknya di sekolah yang menanamkan keislaman lebih karena mereka beranggapan anak soleh lebih utama dibandingkan dengan akademiknya. Respon masyarakat terhadap bangkitnya sekolah umum yang bernuansa keislaman ditanggapi positif, dengan berdirinya sekolah-sekolah bernuansa keislaman. Hal ini ditandai dengan tumbuhnya sekolah Islam lainnya dan siswanya pun tetap banyak, kondisi ini dilihat di SDIT Al-Ikhtiar, SD Islam Al-Azhar, SDIT Al-Fithyan dll.

Selain faktor eksternal, ada juga faktor internal yang mempengaruhi munculnya pendirian SDIT Al-Biruni diantaranya: pertama, tingkat kesempatan memberi kemandirian dan kreativitas individu siswa. Banyaknya jiwa-jiwa kreatifitas yang kurang di sekolah dasar negeri dan swasta dikarenakan sedikitnya waktu yang dapat mereka lakukan di sekolah karena banyaknya siswa dalam satu kelas atau sedikitnya waktu belajar di kelas. Hal ini akan berdampak pada tidak optimalnya perkembangan potensi anak. Dengan kondisi ini, SDIT Al-Biruni dibentuk karena prihatin atas ketidakmandirian dan rendahnya kreatifitas siswa dan diperkuat dengan adanya kesempatan bagi yayasan untuk menyelenggarakan sekolah yang tidak bertentangan pendirian izinnya dengan Kemendikbud. 
Kedua, tingkat pengamalan spiritual anak. Pendirian sekolah ini disebabkan oleh kurangnya pengamalan spiritual pada siswasiswi di Makassar. Hal ini ditunjukkan oleh masih sedikitnya anak-anak dan remaja dengan senang hati menggunakan baju muslimah ke luar rumah. Terdapatnya sekolah Islam yang hanya mewajibkan menggunakan kerudung pada hari Jum'at saja. Seiring perkembangan teknologi anak-anak juga harus dibekali dengan filter untuk memilah acara televisi atau ajakan temannya yang menyimpang atau tidak diridhai oleh Allah SWT.

Ketiga, motivasi. Rendahnya motivasi siswa untuk aktif mendorong sekolah ini menciptakan suasana agar siswa senang dan aktif dalam kegiatan sekolah, oleh karena itu sekolah SDIT ini diharapkan mampu memotivasi siswa dalam berpartisipasi aktif pada pembelajaran dengan adanya student active learning, field trip, kunjungan edukasi, serta pada pelaksanaan kegiatan Islami lainnya. Dan keempat, niat yang luhur. SDIT AlBiruni terdorong untuk menciptakan sosok manusia Indonesia seutuhnya yaitu cerdas dunia akhirat, berprestasi di bidang akademik dengan nilai yang tinggi, dan berakhlak mulia, yaitu salah satunya melalui hafalan Al-qur'an.

\section{Dampak Penyelenggaraan Pendidikan Agama Alternatif}

Dampak dari penyelenggaraan pendidikan agama alternatif ini di antaranya, pertama, bagi peserta didik. Pendidikan agama dapat menciptakan anak yang siap melaksanakan ajaran Islam secara menyeluruh, misalnya; ratarata siswa yang memiliki akhlak yang sholeh biasanya anaknya cerdas dalam akademik. Pada umumnya siswa menjadi lebih santun, mau pergi ke masjid dan mau menghafal Al-qur'an. Mereka juga sangat bersyukur atas nikmat yang telah Allah berikan jika melihat teman-temannya di panti asuhan yang tidak memiliki orangtua. Kedua, kondisi lingkungan yang kondusif dimana antara semua stakeholder (yayasan, pimpinan, guru, TU dan siswa) mempunyai sikap dalam menerapkan Islam secara utuh pada kehidupan sehari-hari sehingga iklim kebersamaan (sense of togetherness), saling memiliki (sense of belongingness), saling percaya (sense of trustworthyness), saling transfer ilmu dan adanya niat yang ikhlas untuk berdakwah terlihat jelas di SDIT Al-Biruni.

Namun di sisi lain, SDIT Al-Biruni yang menggunakan sistem fulldays memerlukan biaya mahal dalam penyelenggaraan sistem pendidikannya, mengikuti hukum pasar yakni supply and demand. Dampak dari kondisi ini adalah tidak semua orang memiliki peluang untuk dapat mengaksesnya.

\section{Kendala dan Pendukung}

Kendala utama dalam menyelenggarakan sekolah full days ini adalah a) kesadaran dan kemampuan pendidik dalam membina siswa. Mereka masih banyak memerlukan pelatihan dan pembinaan dalam mendidik, karena sebagian mereka rata-rata fresh graduate, sehingga perlu dana cukup besar untuk pelatihan yang akan diselenggarakan agar kemampuan mereka sesuai dengan yang diharapkan, b) bagi pendidik waktu persiapan pembelajaran dirasakan sangat kurang; c) metode pembelajaran yang digunakan yaitu active learning memerlukan persiapan yang matang; d) fasilitas yang tersedia cukup memadai, hanya jika ada peralatan yang rusak baru menjadi kendala; e) sumber pembiayaan: berasal dari orang tua, BOS dan dana gratis, tapi belum mencukupi untuk pembiayaan secara keseluruhan; f) motivasi peserta didik dalam mempelajari pendidikan agama cenderung karena mengikuti orang tua, belum kepada tingkat kesadaran perlunya pendidikan agama bagi kehidupan; $h$ ) sistem penyelenggaraan pendidikan keagamaan pada lembaga ini sudah bagus, hanya kontrol hariannya masih belum berjalan, terlihat terlalu percaya pada pendidik.

Adapun faktor pendukung terselenggaranya pendidikan agama di SD IT Al-Biruni di antaranya dapat dilihat dari antusiasme seluruh pihak dalam kegiatan sekolah yang dilakukan secara bersama. Pimpinan yang siap berjuang untuk peningkatan sekolah ke arah yang lebih baik untuk menerapkan Islam dalam segala aspek kehidupan.

Selain itu dengan adanya beberapa pendidik yang sudah memiliki kesadaran bahwa mendidik siswa merupakan suatu ibadah bukan sekedar mencari nafkah, kondisi ini tentunya akan mempengaruhi kualitas proses belajar mengajar di kelas.

Dari sisi potensi siswa dan peranan orang tua yang memiliki harapan besar untuk arah sekolah Islam yang lebih baik, ditambah dengan peran pimpinan dan para pendidik dalam 
pembinaan pendidikan agama, mereka semuanya sebagai pelaksana bagi pembinaan pendidikan agama di sekolah merangkap juga sebagai guru mentor yang diselenggarakan 1 pekan sekali. Semua kondisi ini tentunya turut mendukung keberhasilan output siswa.

\section{Harapan Mendatang}

Dalam meningkatkan akses atau kesempatan mempelajari pendidikan agama (untuk semua kalangan baik ekonomi lemah, menengah dan atas, SDIT Al-Biruni mencoba membuka akses dengan masyarakat di sekitarnya untuk dapat mengkaji pendidikan agama lebih lanjut. Untuk dari kalangan menengah ke atas, dengan bersekolah di SDIT dan SMPIT Al-Biruni serta untuk kalangan lemah, yayasan membuka kesempatan untuk bersekolah di SDIT ini dengan memberikan beasiswa dan dibukanya kelas TPA dan TKA untuk mereka yang sekolah di negeri dan masyarakat sekitar. Dan lebih penting lagi ke depan dalam hal promosi perlu ditingkatkan sehingga akan banyak kalangan atas yang masuk sekolah ini. Bagi kalangan menengah ke bawah diinformasikan kalau sekolah ini pun mengadakan subsidi silang (untuk pemberian beasiswa).

Selanjutnya dalam pengelolaan pendidikan agama, tata kelola dianggap baik apabila pembelajaran terselenggara sesuai pencapaian target, silabus dan lulusan yang dihasilkan optimal. Peningkatan ini dapat dilakukan melalui diusahakannya tata kelola yang ada sesuai dengan standar ISO.

\section{Penutup}

Kesimpulan penelitian ini di antaranya: pertama, latar belakang munculnya Sekolah Dasar Islam Terpadu (SDIT) diawali dengan adanya kebutuhan masyarakat terhadap kondisi lingkungan belajar yang kondusif, nyaman, aman dan Islami bagi siswa dan di sisi lain kondisi pendidikan konvensional tidak memenuhi harapan dan memiliki keterbatasan. Sehingga masyarakat memberikan respon yang positif berdirinya sekolah bernuansa keislaman. Hal ini ditandai dengan tumbuhnya sekolah Islam terpadu. Kedua, SDIT Al-Biruni merupakan sekolah yang berupaya mewujudkan suatu institusi pendidikan yang berbasiskan pada pendidikan secara holistik sebagai upaya untuk memunculkan solusi (jalan keluar) dari keterpurukan model pendidikan yang selama ini diterapkan dan terbukti belum mampu melahirkan manusia-manusia Indonesia yang kompetitif dan sekaligus memiliki integritas dan moralitas yang tinggi.

Ketiga, akses untuk dapat mengikuti SDIT baru dapat dirasakan pada kalangan elit muslim, karena biaya yang mahal dalam penyelenggaraannya. Keempat, format SDIT yang diharapkan ke depan adalah format sekolah yang mampu membantu peserta didik menguasai kompetensi: keagamaan, akademik, ekonomi, dan sosial dengan memperhatikan azas-azas psikologi dan pedagogi, sehingga pendidikan dapat mampu menumbuhkan dan mengembangkan potensi fitrah peserta didik yang memiliki sederet keunggulan kompetitif guna menghadapi segala tantangan ke depan.

Rekomendasi dari kesimpulan di atas di antaranya: dalam meningkatkan akses atau kesempatan mempelajari pendidikan agama, ke depan perlu dipikirkan format sekolah agama alternatif untuk semua kalangan baik ekonomi lemah, menengah dan atas.

Tata kelola penyelenggara sekolah agama alternatif agar sesuai pencapaian target, silabus dan lulusan yang dihasilkan optimal, maka perlu diupayakan ke arah yang sesuai dengan standar pendidikan nasional. Terakhir, Kementerian Agama perlu memberikan masukan yang konstruktif terkait format pendidikan agama alternatif yang telah berkembang di masyarakat.[] 
Arifin, Zuhairansyah. Dilema Pendidikan Islam pada Sekolah Elit Muslim Antara Komersial dan Marginalitas. Riau: Fakultas Tarbiyah dan Keguruan UIN Suska, 2014.

Illich, Ivan. Bebaskan Masyarakat dari Belenggu Sekolah. Jakarta: Yayasan Obor Indonesia, 2000.

Moleong, L.J. Metodologi Penelitian Kualitatif. Cetakan Keenambelas. Bandung: Remaja Rosdakarya, 2000.

Peraturan Pemerintah No. 66 Tahun 2010 Tentang Perubahan Atas Peraturan Pemerintah nomor 17 Tahun 2010 tentang Pengelolaan dan Penyelenggaraan Pendidikan.

Postman, Neil. Matinya pendidikan:Redefinisi nilai- nilai sekolah. Yogyakarta: Jendela, 2001.

Sanaky, Hujair AH. Mengembangkan Madrasah menjadi pendidikan Alternatif. Jurnal Pendidikan Islam, Jurusan Tarbiyah, Fakultas Ilmu Agama Islam Universitas Islam Indonesia, Vol. VIII TH VI Januari 2003.

Tilaar, HAR. Perubahan Sosial dan Pendidikan:Pengantar Paedagogik Transformatif Untuk Indonesia. Jakarta: Grasindo, 2002.

Undang Undang Nomor 20 Tahun 2003 Tentang Sistem Pendidikan Nasional Pasal 3. 
188 Model Penyelenggaraan Pendidikan ... 